SCJR 11, no. 1 (2016): 1-29

\title{
"The Bearers of Unholy Potential": Confessing Church Sermons on the Jews and Judaism
}

\author{
WILLIAM SKILES \\ wskiles@regent.edu \\ Regent University, Virginia Beach, VA 23464
}

As moral and spiritual guides, clergymen in Nazi Germany had a unique opportunity to influence and inform Germans under the domination of the Nazi regime. If an ordinary German were to step inside a church, sit in the pew, and listen attentively to the pastor, what would he or she hear about the Jews and Judaism in this period of extraordinary exclusion and persecution?

The German Protestant churches fractured along theological fault lines when Adolf Hitler and the Nazi regime came to power in January 1933. The popularity of a pro-Nazi faction within the German Protestant churches, the German Christian movement, encouraged Hitler to create a Reichskirche (Reich Church) to unite all Protestant churches under German-Christian leadership in the summer of 1933. This religious movement sought to align Christianity with National Socialist principles, to praise Hitler as Germany's savior, to strip Christianity of its Jewish elements, to apply racialist ideology to Christianity, and to deny leadership or even membership in the church to Christians of Jewish descent. ${ }^{1}$ For many, the German Christian movement went too far, and in September 1933, the Berlin-Dahlem pastor Martin Niemöller organized the Pfarrernotbund (Pastors' Emergency League), which not a year later would become the Confessing Church with a membership of 7,000 pastors (of a total of 18,000 Protestant pastors). ${ }^{2}$ The

William Skiles is an Assistant Professor of History in the College of Arts and Sciences at Regent University, Virginia Beach, Virginia.

This article is adapted from a chapter in my doctoral dissertation, Preaching to Nazi Germany: The Confessing Church on National Socialism, the Jews, and the Question of Opposition. I would like to thank Frank Biess, Deborah Hertz, and the anonymous reviewers for their insightful comments on this article. Thanks also to Robert Ellison and the panel at the American Society of Church History Conference in Edmonton, in April 2016, for helpful critiques of the paper.

\footnotetext{
${ }^{1}$ See Doris Bergen, Twisted Cross: The German Christian Movement in the Third Reich (Chapel Hill: North Carolina Press, 1996); Kurt Meier, Die Deutschen Christen: Das Bild einer Bewegng im Kirchenkampf des Dritten Reiches (Göttigen: Vandenhoeck \& Ruprecht, 1964); and Hans-Joachim Sonne, Die politische Theologie der Deutschen Christen (Göttigen: Vandenhoeck \& Ruprecht, 1982).

${ }^{2}$ Ernst Christian Helmreich, German Churches under Hitler: Background, Struggle and Epilogue (Detroit: Wayne State University Press, 1979), 156; Victoria Barnett, For the Soul of the People: Protestant Protest against Hitler (New York: Oxford University Press, 1992), 63. See also Gerlach, who reports that 6,000 joined by the end of 1933. Wolfgang Gerlach, And the Witnesses Were Silent:
} 
single issue that united members of the Confessing Church was simply that they wanted to halt any National Socialist infringements - whether by the regime or German-Christians-into Christian theology and practice. ${ }^{3}$ This division was about the identity of the Protestant churches in Nazi Germany. The Confessing Church claimed that the Reichskirche had become a corrupted church, and subsequently named itself as the "true" Protestant Church of Germany, faithful to the Reformation confessions. Along with the German-Christians and the Confessing Church members, there were also "neutrals" who simply wished to stay out of the fray and not take a stand one way or the other in relation to the Nazi regime.

Conflict within the German Protestant churches played out in the pulpits. German-Christian pastors preached on themes consonant with National Socialist principles, such as the racial superiority of the "Aryan" race, the destiny of the German nation, the greatness of Germany's "savior," Adolf Hitler, and the perniciousness of the Jewish people. Confessing Church pastors responded to these assertions by looking to the Christian scriptures: Christ is the only savior; the gospel is a universal message, for all people regardless of race or ethnicity; Christians and Jews are spiritual cousins, who share values, traditions, and sacred texts; and Judaism and its scripture are the foundation of Christianity and thus cannot be excised from the German churches.

Despite these differences, historians have demonstrated the pervasiveness of anti-Jewish prejudice in all segments of the German population, including pastors affiliated with the German Christian movement, the Confessing Church, and those who remained "neutral" regarding the Nazi state. ${ }^{4}$ Wolfgang Gerlach has convincingly argued that "Most Christians [in Nazi Germany] saw the Jews as objects of either damnation or evangelization," a position that drastically limited their concern for and actions in support of non-Christian Jews in Germany. ${ }^{5}$ Historians have demonstrated the virtual silence of the German Churches, and the Confessing Church as well, in coming to the aid of European Jewry caught in Nazi persecutions-a silence resulting from ingrained anti-Jewish prejudice. ${ }^{6}$

The Confessing Church and the Persecution of the Jews, translated and edited by Victoria J. Barnett (Lincoln: University of Nebraska, 2000), 33.

${ }^{3}$ Barnett, For the Soul of the People, 5.

${ }^{4}$ Alon Confino, A World Without Jews: The Nazi Imagination from Persecution to Genocide (New Haven: Yale University Press, 2014); Raul Hillberg, The Destruction of the European Jews (New York: Holmes \& Meier, 1985); Robert Michael, Holy Hatred: Christianity, Antisemitism, and the Holocaust (New York: Palgrave Macmillan, 2006); Christopher Probst, Demonizing the Jews: Luther and the Protestant Church in Nazi Germany (Bloomington, IN: Indiana University Press, 2012); and Saul Friedländer, who speaks of the "omnipresence of anti-Semitism in most of the Evangelical Lutheran Church," in Nazi Germany and the Jews, Vol. 2 (New York: HarperPerennial, 2007), 56.

${ }^{5}$ Gerlach, And the Witnesses Were Silent, 7.

${ }^{6}$ Gerlach, And the Witnesses Were Silent; Franklin Hamlin Littell, The Crucifixion of the Jews (New York: Harper \& Row, 1975); Franklin Hamlin Littell and Hubert Locke, eds., The German Church Struggle and the Holocaust (Detroit: Wayne State University Press, 1974); Eberhard Röhm and Jörg Thierfelder, Juden-Christen-Deutsche 1933-1945, Vols 1 \& 2 (Stuttgart, 1990); and Marijke Smid, Deutscher Protestantismus und Judentum 1932/1933 (Munich, 1990). More recently, Peter Fritzsche has argued that there was "general silence about the fate of the German Jews" in the German churches. See Fritzsche, Life and Death in the Third Reich (Cambridge, MA: Belknap, 2008), 119. 
Furthermore, Victoria Barnett has revealed the great complexity and heterogeneity among Confessing Church members; the movement included moderates and radicals, nationalists and antisemites, and even Nazi Party members. The only thing they had in common "was their opposition to the absolute demands of Nazi ideology on their religious faith.",

If we widen the scope of those who opposed the regime to resisters of the Nazi regime and rescuers of Jews, again, anti-Jewish prejudice was widespread. ${ }^{8}$ Historians have demonstrated the pervasiveness of anti-Semitism among the officer's corps in the German military, even among those in the resistance who would conspire against the Nazi regime to end the war and Nazi policies of Jewish persecution. ${ }^{9}$ Among Christians who actively resisted the Nazis and rescued Jews, we find the same prejudice prevalent. ${ }^{10}$ Yet for rescuers and resisters, their sense of honor, duty, and concern and care for their country and the oppressed outweighed traditions of anti-Jewish prejudice, compelling them to act and speak out against the Nazi regime. I will demonstrate that Confessing Church pastors, as citizens who wanted to limit Nazi infringements in the German Protestant churches, also expressed anti-Judaic prejudices, even in criticizing the Nazi regime at the same time.

Regardless of the pervasive anti-Jewish prejudice in the German churches, a nuanced picture emerges if we examine the sermons of the Confessing Church, a vastly underutilized source base. To better understand the pastors' perspectives about Jews and Judaism, historians have long called for a thorough examination of sermons preached to the German masses. ${ }^{11}$ Even though Gerlach's argument about the silence of the Confessing Church in response to Nazi persecution of Jews has found support in the historiography, in my judgment it is impossible to answer the question of silence without first exploring the historical record of clergymen's speech in the pulpit. ${ }^{12}$ This article fills a gap in the historiography, and

\footnotetext{
${ }^{7}$ Barnett, For the Soul of the People, 5.

${ }^{8}$ See Joachim Fest, Plotting Hitler's Death: The Story of the German Resistance, translated by Bruce Little (New York: Metropolitan, 1996), 150; Theodore Hamerow, On the Road to the Wolf's Lair: German Resistance to Hitler (Cambridge, MA: Harvard University Press, 1997), 226; Peter Hoffmann, The History of the German Resistance, 1933-1945, Third Edition (Montreal and Kingston: McGill-Queen's University Press, 1996), 318; Robert Michael, Holy Hatred: Christianity, Antisemitism, and the Holocaust (New York: Palgrave Macmillan, 2006), 165; and Louis Eltscher, Traitors or Patriots? A Story of the German Anti-Nazi Resistance (Bloomington, IN: iUniverse: 2013), 64-66.

${ }^{9}$ See for example, Eltscher, Traitors or Patriots? 64-66; and Hoffman, History of the German Resistance, 318 .

${ }^{10}$ See for example, David Gushee, Righteous Gentiles of the Holocaust: Genocide and Moral Obligation, $2^{\text {nd }}$ Edition (St. Paul, MN: Paragon, 2003); and Nechama Tec's two superb books, When Light Pierced the Darkness: Christian Rescue of Jews in Nazi Occupied Poland (New York: Oxford University Press, 1986), and Resistance: Jews and Christians Who Defied the Nazi Terror (New York: Oxford University Press, 2013).

${ }^{11}$ See Arthur Cochrane, The Church's Confession under Hitler (Philadelphia: Westminster Press, 1962); Walter Zvi Bacharach, Anti-Jewish Prejudices in German-Catholic Sermons, translated by Chaya Galai (Lewiston: Edwin Mellon Press, 1993); and Robert Ericksen and Susannah Heschel, "The German Churches Face Hitler," Tel Aviver Jahrbuch für deutsche Geschichte 23 (1994).

${ }^{12}$ Gerlach, And the Witnesses Were Silent; Franklin Hamlin Littell, The Crucifixion of the Jews; Franklin Hamlin Littell and Hubert Locke, eds., The German Church Struggle and the Holocaust;
} 
aims to explore the messages about Jews and Judaism preached to the German people. My research indicates that Confessing Church pastors occasionally expressed comments either in support of or critical of the Jews and Judaism from the pulpit.

I wish not simply to examine what the pastors said; instead, I wish to explore the reasons why they expressed these views. The motives for these expressions often served a broader purpose than simply relating personal views of Jews and Judaism. These comments from the pulpit reveal that the pastors sometimes wished to connect Christians to the history, traditions, and values of Jews. They sought to preserve the identity and theology of the German churches in the context of Nazi persecution and the German-Christian "Nazification" or "dejudaization" of the Protestant churches. Most surprisingly, the pastors also used anti-Judaic statements as a way to criticize the Nazi regime and its leadership for espousing a racial ideology of "chosen-ness" that undermined basic Christian beliefs. Thus, the pastors' comments about Jews and Judaism most often had a clear purpose that in some way served the interests of the Confessing Church. Furthermore, as will become evident, the prejudice expressed by Confessing Church pastors was predominantly religious in nature, using anti-Judaic tropes to characterize the Jewish people and their religion. Yet the explicit religious prejudice at times incorporates implicit antisemitic expressions, revealing the blurred boundaries between anti-Judaic religious prejudice and racial antisemitism. Lastly, my analysis corroborates the research by Peter Hoffmann and Ian Kershaw, among others, in demonstrating that the German churches were among the only institutions in Germany able to withstand Nazi "coordination" to the regime and its values, thus giving them a degree of freedom to publicly criticize the Nazi regime and its ideology. ${ }^{13}$

After searching archives, libraries, and used bookstores throughout Germany, I analyzed 910 sermons by ninety-five Confessing Church pastors-all the sermons I could confirm were delivered by Confessing Church members. ${ }^{14}$ While some sermons do not clearly identify the location in which they were delivered, we can determine that the sermons were preached throughout Nazi Germany, in small towns and large cities throughout the various regions, from SchleswigHolstein in the north, to Bavaria in the south; from Westphalia in the west, to Saxony in the east. Of all the sermons, 717 were found in book or pamphlet collections published either during or shortly after the Nazi dictatorship. The

Eberhard Röhm and Jörg Thierfelder, Juden-Christen-Deutsche 1933-1945, Vols. 1 \& 2; and Marijke Smid, Deutscher Protestantismus und Judentum 1932/1933.

${ }^{13}$ See Barnett, For the Soul of the People, 181-185; Hoffmann, The History of German Resistance, 13; Ian Kershaw, Hitler, the Germans, and the Final Solution (New Haven: Yale University Press, 2008), 166.

${ }^{14}$ The sermons were all delivered by members of the Confessing Church, from a variety of positions, including newly ordained pastors, superintendents, and theologians. Many well-known Confessing Church leaders contributed sermons to the source base for this research, such as Hans Asmussen (fifty-eight sermons), Karl Barth (thirty), Dietrich Bonhoeffer (fifty-six), Friedrich von Bodelschwingh (thirty-nine), Helmut Gollwitzer (nine), and Hans Iwand (eighteen). 
remaining 211 were unpublished sermons found in archives. ${ }^{15}$ Some of the sermons are dated, while others lack dating or time references. Many can only be categorized generally as pre-war, or within a certain time frame (e.g. 1941-1943). So it is virtually impossible to determine how many sermons were delivered in any given year or month. However, I have determined that only 255 of the 910 sermons were delivered during World War II. When war broke out, pastors began to leave the pulpits and join the war, either voluntarily or involuntarily through the draft. For example, Christian Helmreich argues that by $1941,40 \%$ of Protestant pastors were mobilized in the army or navy. By October 1944, $45 \%$ of all Protestant pastors and $98 \%$ of non-ordained vicars and candidates for ministry were mobilized for war. This mean fewer qualified pastors to preach on the home front, and thus fewer sermons in the historical record. ${ }^{16}$

I have found that seventy sermons of the 910 in the collection expressed views that contributed to how their congregations perceived Judaism and the Jews of Nazi Germany. The expressions were evenly divided in support of and against the Jewish people. In forty sermons, Confessing Church pastors made anti-Judaic statements that corroborated the Nazi antisemitic narrative that the Jews and their religion are inferior. At the same time, in another forty sermons, pastors expressed support and solidarity with the Jewish people, honored Judaism as a foundation of the Christian religion, and even spoke out against the Nazi persecution of the Jews (ten sermons included both comments supportive and critical of Jews, and thus were only counted once in the total of seventy sermons). These sermons reveal not only ambivalence among Confessing Church pastors about Judaism and the Jewish people, but a millennia-long ingrained prejudice that often came to the surface. As some of these sermons demonstrate, even when a pastor supported the Jewish people or affirmed the value of Judaism as a basis of Christianity, anti-Judaic comments undermine these messages.

My research is significant, first, because it is the only study to extensively treat expressions of support for Jews as well as the nature of anti-Jewish prejudice expressed from the Christian pulpits in Nazi Germany. In short, my analysis treats seriously sermons as a source base for understanding Christians' perceptions of Jews and Judaism in Nazi Germany. To underscore how unique this approach is, I have found only one monograph to treat the sermons of German churches, the Israeli historian Walter Zvi Bacharach's Anti-Jewish Prejudices in GermanCatholic Sermons (2000). ${ }^{17}$ While Bacharach examines Catholic sermons of the nineteenth century, and not Protestant sermons from 1933-1945, he concludes

\footnotetext{
${ }^{15}$ The archives I utilized were the Evangelisches Zentralarchiv in Berlin, the Landeskirchliches Archiv der Evangelischen Kirche von Westfalen in Bielefeld, the Archiv der Evangelischen Kirchen im Rheinland in Düsseldorf, the archive of the National Library of Scotland in Edinburgh, and the University of Iowa Libraries, Special Collections in Iowa City.

${ }^{16}$ But we should add to this also that sermons were likely destroyed in the war. As I learned conducting my research, the war might have led to the destruction of sermons by leading figures, such as Gerhard Jacobi of the Gedenkniskirche in Berlin. These sermons may have been lost from the historical record.

${ }^{17}$ Bacharach, Walter Zvi. Anti-Jewish Prejudices in German-Catholic Sermons, Translated by Chaya Galai. Lewiston: Edwin Mellon Press, 1993.
} 
that Catholic theology as expressed and disseminated in sermons throughout Germany greatly contributed to the prevailing view that Jews were inferior, criminal, spiritually corrupt, and thus deserving of divine punishment. ${ }^{18}$ However, more scholarship needs to be done to judge whether the Nazi era marks a shift in the expressions about Jews and Judaism in the Protestant churches from the Weimar or Imperial eras.

Second, this research is significant because it fills a lacuna in the historiography by clarifying the nature of anti-Jewish prejudice in Confessing Church pulpits, and demonstrates that it was predominantly religious in nature (though at times racial prejudice comes to the surface as well), in stark contrast to the virulent antisemitism espoused by pastors in the German Christian movement or by members of the Nazi regime and its propaganda machine. Third, this research reveals that Confessing Church pastors employed anti-Jewish prejudice, not simply to denigrate the Jews, but to purposely challenge the Nazi regime and its racial policies and ideology. And fourth, this research challenges, or rather nuances, the common argument that pastors of the German churches remained silent as their Jewish neighbors faced unprecedented persecution by the Nazi regime. While the support of the Confessing Church pastors for Jews was admittedly meager, we now have a greater understanding of what they actually said from the pulpit in support of the Jews and Judaism in Nazi Germany.

\section{Confessing Church Expressions of Anti-Judaism}

After analyzing 910 sermons of the Confessing Church, I found that forty contain messages that express prejudice against the Jewish people or Judaism, voiced by fifteen of the ninety-five Confessing Church pastors examined for this study. ${ }^{19}$ While the number of sermons may be small, they are significant to our understanding of the messages Confessing Church pastors delivered publicly about the Jews and Judaism.

All forty sermons that express prejudice against the Jewish people or Judaism reflect traditional Christian anti-Judaism, specifically the following six elements: first, the general view that the Jews are a stubborn or wayward people; second, the view that Christianity is superior because it emphasizes grace and freedom over Judaism's purported emphasis on law and works; third, the claim that the Jews are a stubborn people for rejecting Jesus, or that they are actually responsible for putting him to death (and thus, the charge of deicide); fourth, the perception that God has or is currently punishing the Jews for the rejection of Je-

\footnotetext{
${ }^{18}$ Bacharach, Anti-Jewish Prejudices in German-Catholic Sermons, 130-133.

${ }^{19}$ The names of the pastors are as follows: Karl Barth (2 times); Friedrich von Bodelschwingh (3); Dietrich Bonhoeffer (1); Friedrich Delekat (1); Otto Dibelius (1); Hermann Diem (1); Robert Frick (1) Heinrich Grüber (1); Hanns Lilje (1); Paul Hinz (4); Martin Niemöller (7); Julius Sammentreuther (8); Hermann Sasse (1); Karl von Schwartz (4); Hans von Soden (1). Of the forty sermons that expressed anti-Judaic sentiments, thirty-one (76\%) were based on New Testament texts. As we will see later, pastors who expressed support for the Jews and Judaism used the Hebrew Bible much more often $(47 \%)$.
} 
sus; fifth, the belief that upon the rejection of Jesus and the establishment of the Church, the Jews have ceased to be the people of God; and sixth, a generalized sentiment that hopes for the mass conversion of the Jews, reflecting a belief in the inferiority of Judaism and the lack of salvation for the Jewish people. ${ }^{20}$ The sermons of Confessing Church pastors reveal anti-Judaism or non-rational religious prejudice, which is based on religious convictions or interpretations of scripture and history. ${ }^{21}$

Yet at times pastors used anti-Judaic tropes that implicitly reference antisemitism, an ideology that asserts the racial inferiority or perniciousness of the Jewish people. ${ }^{22}$ For example, the assertion that the Jews have a history of "waywardness" in rejecting Christ from the first century to the twentieth presumes not simply a religious denial of Christ, but implies a biological predisposition that passes from one generation to the next. Thus, these sermons reveal that the line between anti-Judaism and antisemitism can easily become blurred. A faith-based anti-Judaism can easily become a racially-based antisemitism. ${ }^{23}$

Nevertheless, I have found no evidence of antisemitic expressions that stand alone without mention of religious prejudice. In other words, the primary basis of the anti-Jewish prejudice is religious conviction, which at times implicitly draws on antisemitic tropes. The basis of the prejudice is not racial ideology. These sermons reveal continuity in the anti-Judaic prejudice expressed by clergymen throughout the history of the Christianity. Thus, in the interests of efficiency and precision in examining specifically religious primary sources, it is important to maintain a distinction between centuries-old religious anti-Judaism and modern racial antisemitism. I will use the terms "anti-Judaism" and "antisemitism" as two forms of prejudice, though forms that can and often do interact.

We must also keep in mind the larger context in which anti-Jewish prejudice was expressed in the German Protestant churches. From the start, the main concern of the Confessing Church was to oppose the attempts of the German Christian movement to "Nazify" the churches by attempting to institutionalize a racial criterion, stipulated in an "Aryan paragraph," to be adopted into church law throughout the German states, thus limiting church leadership, ordination, and even membership to "Aryan" Germans only. ${ }^{24}$ The German Protestant churches

\footnotetext{
${ }^{20}$ See James Carroll, Constantine's Sword: The Church and the Jews (New York: Houghton Mifflin, 2001); Léon Poliakov, The History of Anti-Semitism, Vol. 1, From the Time of Christ to the Court of the Jews, translated by Richard Howard (New York: Vanguard, 1965); Dan Cohn-Sherbok, The Crucified Jew: Twenty Centuries of Christian Anti-Semitism (Grand Rapids: Eerdmans, 1997).

${ }^{21}$ See Langmuir, History, Religion, and Antisemitism, 152, 252-255; and Michael, Holy Hatred, 8284.

${ }^{22}$ See Michael Burleigh and Wolfgang Wippermann, The Racial State: Germany 1933-1945 (Cambridge University Press, 1991); and John Weiss, Ideology of Death: Why the Holocaust Happened in Germany (Chicago: Ivan R. Dee, 1996).

${ }^{23}$ Michael, Holy Hatred, 5-6. See also Carroll, Constantine's Sword, 22; and Daniel Goldhagen, A Moral Reckoning: The Role of the Catholic Church in the Holocaust and its Unfulfilled Duty of Repair (New York: Knopf, 2002), 78-9.

${ }^{24}$ See Barnett, For the Soul of the People, 128-129; Bergen, Twisted Cross, 88-93; Gutteridge, German Evangelical Church and the Jews, 91-96; and Helmreich, German Churches under Hitler, 144147.
} 
vigorously debated the "Aryan paragraph" and they took various positions, which at times reveal anti-Jewish prejudice. Regional churches sought the advice of theological faculty, and two of the more well-known responses were from the theological faculty at the universities of Marburg and Erlangen. The Marburg faculty explicitly and unambiguously opposed the "Aryan paragraph": any person of Jewish descent, who accepts Christianity and is baptized, is a full-fledged member of the Church. ${ }^{25}$ In contrast, the Erlangen faculty's response was ambiguous and equivocal in its answer: historically the church has required biological requirements of faculty (e.g. age, sex, and physical capabilities), so the church could add other biological requirements; at the same time, for a church to prosper, it would help for a pastor to be of the same people as his congregation (a Bavarian leading Bavarians, for example); perhaps separate churches for Jewish Christians might be the answer. ${ }^{26}$

One of the very few times that the Confessing Church leadership stridently condemned the antisemitism of the Nazi regime is the memorandum of May 28, 1936, issued by the Provisional Church Government and sent directly to Adolf Hitler. Though meant to be a private memorandum for Hitler, the press got its hands on it and published it at home and abroad. ${ }^{27}$ The letter criticized the regime on a range of issues, including the problems of disunity among the Protestant churches, the deification of the Nazi state and Hitler himself, and concerns about de-Christianization in Nazi Germany. ${ }^{28}$ But its condemnation of antisemitism was especially striking, if only because it was so rare a criticism delivered directly to Hitler: "when within the concepts of National Socialist Weltanschauung (worldview) an anti-Semitism is forced on Christians which demands hatred of the Jews (Judenhaas), there stands opposed to this the Christian command of love your neighbor." ${ }^{, 29}$ The Nazi regime reacted with vehemence, arresting several pastors and theologians responsible for the letter, including a Jewish man, Friedrich Weissler, an attorney who worked with the Provisional Church Government, and who was sent to Sachsenhausen and murdered. The Nazi reaction reveals the repercussions of speaking out publicly against the Nazi regime, especially against its persecution of the Jews.

Nevertheless, the consensus among historians is that throughout the Third Reich, Confessing Church pastors limited their concerns about Nazi racial policies to their impact on Jewish Christians - to Christians of Jewish descent within the churches - and failed to concern themselves about the persecution of Jews as Jews under the Nazi regime. ${ }^{30}$ In the context of Nazi Germany, one could argue

\footnotetext{
${ }^{25}$ Barnet, For the Soul of the People, 129; and Helmreich, German Churches under Hitler, 145.

${ }^{26}$ Gerlach, And the Witnesses Were Silent, 39-41; Green, Lutherans against Hitler, 133-142; and Helmreich, German Churches under Hitler, 145-146.

${ }^{27}$ Helmreich, German Churches under Hitler, 200-201.

${ }^{28}$ Barnett, For the Soul of the People, 83-84; Helmreich, German Churches under Hitler, 199.

${ }^{29}$ Quoted in Helmreich, German Churches under Hitler, 200.

${ }^{30}$ See Kenneth C. Barnes, "Dietrich Bonhoeffer and Hitler's Persecution of the Jews," in Betrayal: German Churches and the Holocaust, edited by Robert P. Ericksen and Susannah Heschel (Minneapolis: Fortress Press, 1999), 128; Barnett, For the Soul of the People, 142; Robert P. Ericksen,
} 
that anti-Jewish expressions from the pulpit indirectly serve to support Nazi racial policies because they are clearly aimed at criticizing the Jewish community.

It is striking to note that the religious prejudice expressed from the Confessing Church pulpits often serve a specific purpose, whether to demonstrate the spiritual or moral superiority of Christians to Jews, or remarkably, to criticize Nazis and National Socialism. Let us start with the former, sermons that demonstrate the superiority of Christianity and the inferiority of Judaism, a common theme not only in the history of the Nazi era, but in the history of Christian anti-Jewish prejudice through the centuries. ${ }^{31}$

A sermon by Pastor Paul Hinz of Kolberg illustrates this theme well. Hinz was a leading member of the Confessing Church in Pomerania, even serving as a leader on the Pomeranian Provincial Council of Brethren (Bruderrat, or governing council). On June 20, 1935, Hinz delivered a sermon that uses a Christian interpretation of history to criticize Jews and Judaism. Keep in mind, this sermon comes after the Nazi regime already began its persecutions against German Jews, such as the Nazi-sponsored boycott of all Jewish shops on April 1, 1933, and the passage of the Civil Service Law of April 7, 1933, effectively prohibiting Jews and socialists from national, state, and local civil service employment, including for example, school teachers, professors, and government officials and employees. $^{32}$

Hinz took as his biblical passage Romans 10:1-5, wherein the Apostle Paul both expresses his displeasure with the Jews' "ignorance of the righteousness that comes from God," and also his hope that they will one day experience salvation in Christ. But Hinz takes Paul's criticism even further, and argues that because Israel rejected Christ in "stubborn blindness" to God, Israel was no longer God's chosen people, but instead "under the judgment of God's wrath." 33 He contends that God cast the Jews aside and welcomed all peoples throughout the world into the Church. Furthermore, he contends that the Jews trust in their own descent, in blood and race, and in their own chosen-ness-perhaps indirectly comparing

Complicity in the Holocaust: Churches and Universities in Nazi Germany (New York: Cambridge University Press, 2012), 106; and Gerlach, And the Witnesses Were Silent, 7.

${ }^{31}$ My analysis follows the work of historians such as Baranowski, Ericksen, Hayes, among others, that anti-Judaism was a widespread characteristic of early $20^{\text {th }}$ century German Protestantism. See Shelley Baranowski, "The Confessing Church and Antisemitism: Protestant Identity, German Nationhood, and the Exclusion of the Jews," in Robert P. Ericksen and Susannah Heschel, eds., Betrayal: German Churches and the Holocaust (Minneapolis: Fortress Press, 1999); Kenneth Barnes, Nazism, Liberalism, and Christianity: Protestant Social Thought in Germany and Great Britain 1925-1937 (Lexington, KY: University Press of Kentucky, 1991), 140-141; Doris Bergen, "Catholics, Protestants, and Antisemitism in Nazi Germany," Central European History 27 (1994): 329-348; Wolfgang Gerlach, And the Witnesses Were Silent: The Confessing Church and the Persecution of the Jews, translated and edited by Victoria Barnett (Lincoln, NB: University of Nebraska Press, 2000), 236; Stephen R. Haynes, "Who Needs Enemies? Jews and Judaism in Anti-Nazi Religious Discourse," Church History 71:2 (June 2002), 341-367; and Uriel Tal, "On Modern Lutheranism and Jews," in Year Book of the Leo Baeck Institute (London: Secker \& Warburg, 1985), 203-213.

${ }^{32}$ Kirk, Nazi Germany, 41-42.

${ }^{33}$ Paul Hinz, Sermon manuscript on Romans 10:1-15, 30 June 1935, Collected Sermons of Paul Hinz, Evangelisches Zentralarchiv, Berlin (EZA) 766/38. 
them to Nazis (more of this to come). But Hinz does not stop here. He reminds his congregation of the anti-Judaic theme of the Jews' curse in Matthew 27:25. According to the gospel writer, "the Jews" demanded that Pilate crucify Jesus and free Barabbas: "[Jesus'] blood be on us and on our children!" This curse, Hinz contends, has "uncannily" been accomplished throughout history and even until this day. ${ }^{34}$ The sermon takes a biblical text that is critical of Jews, and adds layer upon layer of traditional Christian anti-Judaic theology that ends with a "proof" for all to see and verify - the punishment of the Jews in history. These comments are also a good example of how religious anti-Judaic prejudice can imply racial antisemitism: Jewish "stubborn blindness" has been passed down biologically from one generation to the next; the "blood guilt" carries on to the modern age resulting in God's continued punishment.

Just as concerning are expressions that blame "the Jews" for rejecting or killing Christ because of their supposed hatred, revealing their spiritual or moral inferiority. I have found fourteen examples of this trope by nine different pastors. ${ }^{35}$ These expressions vary widely in judgment and blame. Many of these refer simply and as a matter of fact to the Jews' hatred of Jesus. Four of these retell the trial and crucifixion of Jesus and in so doing argue that "the Jews" hated Jesus and rejected him. For example, in a sermon during the Second World War, Pastor Otto Dibelius, the general superintendent of the Brandenburg Land church, calls the crucifixion a "great [attempt] of human hatred," and Pastor Bodelschwingh said in 1944 that "Jewish hatred of Christ is a contagious force." ${ }^{36}$ Other pastors were more explicit that the Jews actually killed Christ. This point is tremendously significant as the charge of deicide was often used during the Holocaust to justify violence against the Jewish people. ${ }^{37}$ The historian Irving Greenberg has noted "literally hundreds" of instances where this kind of statement was made to justify antisemitic violence. ${ }^{38}$

The sermons that express Jewish hatred for Jesus do not aim for historical accuracy, but paint the entire Jewish population as opponents if not outright enemies of Christ and Christianity. While these statements about Jewish hatred for Jesus may suggest to Christians listening in Nazi Germany that their Jewish neighbors still harbor this hatred, the implication may not have been intended. Nevertheless, we should remember the context in which these sermons were delivered. As Nazi persecutions changed from public policies of exclusion from

\footnotetext{
${ }^{34}$ Hinz, Sermon manuscript on Romans 10:1-15, EZA 766/38.

${ }^{35}$ Thirteen of the 14 sermons were based on New Testament texts, while only one was based on the Hebrew Bible (from the book of Micah). At the same time, eleven of the fourteen were based on the gospels (and five from the book of Matthew). This evidence suggests that Confessing Church pastors interpreted the New Testament, and especially the gospels, in a way conducive to the most destructive of anti-Judaic tropes, that the Jews were responsible for the death of Jesus of Nazareth, and that God had cursed them as a punishment.

${ }^{36}$ Friedrich von Bodelschwingh, Lebendig und Frei: Predigten, 2. Folge (Bielefeld: Verlagshandlung der Anstalt Bethel, 1947), 170.

${ }^{37}$ Michael, Holy Hatred, 182.

${ }^{38}$ Irving Greenberg, "Cloud of Smoke, Pillar of Fire," in Auschwitz: Beginning of a New Era? Edited by Eva Fleischner (New York: KTAV, 1997), 308.
} 
German social and civil life, to the increasing "Aryanization" of Jewish property and businesses in 1937, to the ghettoization and finally extermination of Jews during World War II, the effects of these sermons on the German public could only have legitimated Nazi oppression and perhaps even cooled the consciences of Christians who may have been concerned for their Jewish neighbors. Christian anti-Judaic theology served to "numb" Christians to the suffering and persecution of their Jewish neighbors, and it became a hindrance for them to stand up and protest the Nazi dictatorship, to act on behalf of their Jewish neighbors.

Moreover, anti-Jewish sentiments fractured relationships even within congregations. Robert Gellately's study of the attitudes of Germans throughout the Nazi period concerning the regime and its treatment of Jews reveals that many "ordinary" Christians supported Nazi measures, such as the decree of 15 September 1941 forcing Jews aged seven and older to wear the yellow star. ${ }^{39}$ Gellately writes of the consternation of many Christians when the yellow star revealed just how many Christians of Jewish descent attended church services: "In some parts of the country, Protestant churchgoers were displeased to note how many (converted) Jews went to church, and demanded of their ministers that they should not be asked to take communion next to these Jews, whom they wanted forbidden to attend common services." Anti-Jewish beliefs resulted in the "shunning" of Christians of Jewish descent, the loss of fellowship and mutual support, and the restriction of rites and sacraments, including communion. ${ }^{41}$

If we break down the years in which Confessing Church pastors expressed these anti-Judaic comments, several important observations can be made. First, twenty-eight of the thirty-five sermons, whose dates are known, were expressed between 1933 and 1939, prior to the outbreak of World War II. Also, more than half of the expressions were given between 1933 and 1936. Given the low figures we are working with, we cannot claim that these percentages are representative of all Confessing Church sermons. Yet they indicate a decrease in the frequency of anti-Judaic expressions from 1936 until the end of the war, suggesting that pastors may have wanted to "tone down" criticisms of Jews as Nazi persecutions increased.

Furthermore, most of the sermons that speak of "the Jews" rejection or killing of Christ were delivered before the start of World War II. Nine of the fourteen occurred between 1933 and the outbreak of war, while four occurred during the

\footnotetext{
${ }^{39}$ Robert Gellately, Backing Hitler: Consent and Coercion in Nazi Germany (New York: Oxford University Press, 2001), Kindle edition, location 3387.

${ }^{40}$ Gellately, Backing Hitler, Kindle edition, location 3387. In addition, Helmreich reports that in 1939 "non-Aryan" Christians totaled about 14,000 people - the largest number being Lutheran at 10,461. Add to this number approximately 5,000 "Mischlinge," and the result is a small but significant group. See Helmreich, German Churches under Hitler, 329-330.

${ }^{41}$ Barnett, For the Soul of the People, 132. See also Bankier, Germans and the Final Solution, 124125. Bankier contends that even in 1941, upon the introduction of the yellow star in Germany, many were "surprised how many Jews still lived in Germany, and praised the labeling, which brought them into the open."
} 
war itself. ${ }^{42}$ Given the general decrease in the 910 extant sermons we have that were delivered during the war compared to the pre-war period, this proportion may not be surprising. However, eight of the sermons occur in just the first few years of the Nazi regime, into 1936, just after the Nazi persecution of the Jewish people reached a new stage in the Nuremberg Laws of 1935, which provided a legal basis for legal discrimination throughout the Nazi dictatorship. ${ }^{43}$ The Nuremberg Laws stripped Jews of citizenship, prohibited sexual relations and marriage with "Aryans," and further restricted the rights of Jews, such as the prohibition of Jews to fly the German flag. The laws represent another step in the permanent exclusion of Jews from German public life.

The fact that about two-thirds of the sermons that contain anti-Judaic expressions were delivered in 1939 or earlier, may reflect a growing awareness of the Nazi persecution of the Jews and a subsequent desire to limit criticism toward them, or it may simply reflect a desire among pastors to adjust the content of their sermons in wartime.

Let us look at another example of a sermon that expresses criticism for Jewish hatred of Jesus, this one from the preeminent leader of the Confessing Church, Martin Niemöller. In a Passion Service only three Sundays before Easter in 1937, he preached a sermon on Pilate's question to "the masses" at the Passover celebration, would they rather free "Christ or Barabbas?" (Mt 27:17). The first paragraph is striking because of the nonchalance with which Niemöller expresses what he considers a commonplace perception:

[W] hen we hear the story of Christ's Passion we have a feeling of sympathy... with the figure of this Roman, Pilate, whereas we most emphatically dissociate and separate ourselves from all the others who helped to bring about the death of Jesus. The cold hatred of the Jewish authorities fills us with horror, the groundless and unfathomable treachery of Judas makes us shudder, and the pusillanimous fanaticism of the multitude rouses our contempt [emphasis added]. ${ }^{44}$

Niemöller does not discuss his view of the Jews again in this sermon, but this first paragraph alone reveals what may be a commonly held view in Germany that the Jews - its leaders and the masses - were responsible for the execution of Jesus. Yet Niemöller invokes in the congregation sympathy for Pilate, the Roman governor who actually had Jesus tortured and crucified as an insurrectionist.

Remarkably, most of the anti-Judaic comments in these forty sermons were not from pastors on the fringe of the Confessing Church, expressing views that would have embarrassed their colleagues. In fact, many of these pastors are widely considered heroes of the Confessing Church. For example, Dietrich Bonhoeffer

\footnotetext{
${ }^{42}$ One of the fourteen does not provide enough information to determine if it was delivered before or during the war.

${ }^{43}$ Helmreich, German Churches under Hitler, 190.

${ }^{44}$ Martin Niemöller, God is My Fuehrer: Being the Last Twenty-Eight Sermons, translated by Jane Lymburn (New York: Philosophical Library, 1941), 169.
} 
ran an underground seminary before participating in a conspiracy against Hitler and the regime. And Martin Niemöller courageously spoke out against Nazi intrusions in church administration and theology, and also against persecutions of its pastors. They were admired leaders in their movement, and yet they expressed anti-Judaic views that could only have alienated Christians from their Jewish neighbors or confirmed their already-existing antisemitism. If the best and the brightest of Confessing Church pastors, the most courageous and insightful, made such anti-Judaic statements in their sermons, we can conclude along with Baranowski, Gerlach, and Haynes, among others, that these sentiments were deeply ingrained in Christian theology and that they were widespread. ${ }^{45}$

While we find many examples of Confessing Church pastors using antiJudaic tropes to demonstrate the moral superiority of Christians over Jews, or of Christianity over Judaism generally, another common and quite remarkable usage of anti-Judaic expressions is to compare Jews to Nazis, or Judaism to National Socialism. Confessing Church pastors would take common anti-Judaic perceptions of Jews as a wayward people obsessed with race, and use them to criticize Nazis and National Socialism for similar "sins." Consider an example from Pastor Karl von Schwartz from Braunschweig, who published a sermon late in 1933, but possibly preached earlier, in which he argued that, "The whole history of Israel from Sinai to the Pharisees is a history of waywardness. And if today this people had all the gold in the world and all the power in the world, the waywardness will remain: it should be a light to lighten the Gentiles... Also the Aryan race is no exception, despite all the idealization." ${ }^{\text {"46 }}$ Schwartz presents the Jews as stubborn in their own beliefs. The implication is that this people is not to be trusted, but kept at a distance as a sign to the world of a people gone astray.

This sermon is an example of how anti-Judaic prejudice can easily transition to antisemitic expression. "Waywardness" is explicitly presented as a spiritual condition, but the implication is that it is biologically passed down from generation to generation to "be a light to the Gentiles." And furthermore, the assertion that the waywardness would remain even if the Jews "had all the gold in the world" implies the antisemitic trope of Jews as a greedy, profiteering people in control of the world's financial systems. In this example by Schwartz, the antiJudaic prejudice provides the foundation for the antisemitic trope.

But having said all this, Schwartz continues and asserts that "Aryans," despite their glorification in Nazi propaganda, must take a lesson from the Jewish people: even the "Aryan race" is in need of repentance and must humbly submit to and follow God or face God's punishment. Schwartz's implication is that the two groups are not all that different— both are wayward and need to submit to God.

\footnotetext{
${ }^{45}$ See Baranowski, "The Confessing Church and Antisemitism"; Barnes, Nazism, Liberalism, and Christianity, 140-141; Bergen, "Catholics, Protestants, and Antisemitism in Nazi Germany," 329-348; Gerlach, And the Witnesses Were Silent, 236; Haynes, "Who Needs Enemies?" 341-367; and Tal, "On Modern Lutheranism and Jews," 203-213.

${ }^{46}$ Karl von Schwartz, Gottes Wort an Gottes Volk: Ein Jahrgang Predigten (Braunschweig: Hellmuth Wollermann Verlagsbuchhandlung, 1933), 58.
} 
The historian Uriel Tal has shown - using sources as varied as academic lectures, private letters, and published articles and books - that the leadership of the Confessing Church commonly made comparisons between Jews and Nazis in their conceptions of race and Volk, as a means to criticize the Nazi regime, its leadership, and ideology, especially after the mid-1930s. ${ }^{47}$ Likewise, Stephen Haynes has demonstrated the common usage of anti-Judaic tropes in the anti-Nazi rhetoric among leaders in the German churches, especially in the writings of Dietrich Bonhoeffer. ${ }^{48}$ Moreover, the criticism of comparing Jews to Nazis as both creators of a false ethno-nationalist identity implicitly draws on the traditional antisemitic trope of "tribalism," or the belief in the superiority of one's own racial or ethnic group over others. ${ }^{49}$

My research demonstrates that Confessing Church leaders made these same criticisms in sermons as part of worship services, and not simply in the secular public sphere. Pastors utilized overt anti-Judaic tropes with implicit antisemitic overtones, in a religious context, to condemn a political system and its ideology.

Confessing Church pastors not only used anti-Judaic tropes to condemn those outside the German churches, but those within, specifically the pro-Nazi German Christian movement. The sermons reveal a deepening rift in German Protestantism between the German Christian movement and the nascent Confessing Church. The confrontation came to a head in November 1933, in the Berlin Sportspalast, where the headline speaker, a German-Christian leader named Dr. Reinhold Krause, gave a speech attacking the Hebrew Bible for its legalistic morality and condemning the Apostle Paul for "Judaizing" Christianity, ideas that would greatly increase in popularity among the German Christian movement by the end of the 1930s. ${ }^{50}$ Following Krause, members of the German Christian movement condemned "Rabbi Paul" and his theology "with its scapegoats and inferiority complex.".51

While sermons of the Confessing Church reveal centuries-old anti-Jewish sentiments, such as the Jewish rejection of Christ, the sermons of the German Christian movement overtly expressed racial prejudice meant to exclude Jews from the church and German society. For example, one sermon by Heinrich Kalb from Wiessenburg, delivered in 1937, entitled Juden Christ - deutscher Christ? (Jewish Christian - German Christian?), argues for the separation of Jewish Christians from "Aryan" congregations, which he sums up in the phrase, "Ger-

\footnotetext{
${ }^{47}$ Uriel Tal, "On Structures of Political Theology and Myth in Germany Prior to the Holocaust," in Yehuda Bauer and Nathan Rotenstreich, eds., The Holocaust as Historical Experience (New York, 1981), 122.

${ }^{48}$ Haynes, "Who Needs Enemies?" 350-367.

${ }^{49}$ Haynes, "Who Needs Enemies?" 344-347.

${ }^{50}$ Bergen, Twisted Cross, 17. See also Susannah Heschel, The Aryan Jesus: Christian Theologians and the Bible in Nazi Germany (Princeton, NJ: Princeton, 2008). Heschel examines the history of how the German-Christians established the Institute for the Study and Eradication of Jewish Influence on German Religious Life in 1939 with the aim to "Aryanize" Jesus and the New Testament.

${ }^{51}$ Bergen, Twisted Cross, 158.
} 
many for Germans, and also in the Church!" ${ }^{52} \mathrm{He}$ and those in the German Christian movement wished to purify the German churches of all "foreign" elements, particularly church leaders of "foreign" backgrounds. ${ }^{53}$ "Only German men may speak to the German people from German pulpits; not Turks, Chinese, or even Jews!",54

The German Christian movement so transformed the theology, practice, and ethics of Christianity through the racial principle of "Aryan" supremacy that it substantively altered the meaning and message of Christianity. To the GermanChristian, the gospel is not universal, baptism is effective only for "Aryans," and the church must be racially segregated. In other words, the movement engaged in a process of changing the fundamental elements of Christianity, transforming the religion into a Nazi-based organization. In fact, to many Christians in Nazi Germany, the German Christian movement was "barely recognizable as Christian." 55 For example, the German Christian movement celebrated Hitler as a savior of the German people, and made efforts to transform Christianity into a volkish religion.

The German Christian movement rejected the canonicity of the Hebrew Bible, and made controversial claims about the New Testament, such as the assertion that Jesus was an "Aryan," and that a core element of the gospel message was hatred of the Jews. ${ }^{56}$ Susannah Heschel has argued that GermanChristians spearheaded the formation of an organization in April 1939, the Institute for the Study and Eradication of Jewish Influence on German Religious Life (Institut zur Erforschung und Beseitigung des jüdisches Einflusses auf das deutsche kirchliche Leben), a government-sponsored and church-supported institute dedicated to eradicating Jewish influence from Christianity. ${ }^{57}$

Confessing Church pastors responded publicly in the pulpits to what they considered gross heresy in the German-Christian movement, though at times invoking anti-Judaic tropes. For example, in late August 1935, Niemöller preached a sermon entitled, "The Office of the Church," in which he combats the GermanChristians and their attack on the Hebrew Bible. But in so doing, he asserts that ancient Judaism was legalistic and works-oriented; he comments that Paul's opponents are Christians "of Jewish origin" and thus "set a particularly high value on the law." ${ }^{, 58} \mathrm{He}$ stated this not because he wanted his congregation to know that first-century Judaism was legalistic, but to demonstrate to the modern-day critics of Paul that the apostle himself fought against Judaism's legalism. This is the crux of the problem for Niemöller. If the German Christian movement condemns Paul and his "Jewish" teaching, and if Paul's writings are in part foundational for the Christian faith, then the Christian faith itself is gravely undermined. Niemöl-

\footnotetext{
${ }^{52}$ Heinrich Kalb, „Judenchrist - deutscher Christ?“ in Deutsches Christentum, dargestellt in Predigt und Vortrag (Nürnberg: Fr. Städler, 1937), 21.

${ }^{53}$ Bergen, Twisted Cross, 82-83.

${ }^{54}$ Kalb, ,Judenchrist - deutscher Christ?" in Deutsches Christentum, 19.

${ }^{55}$ Bergen, Twisted Cross, 2.

${ }^{56}$ Bergen, Twisted Cross, 142-154.

${ }^{57}$ Susannah Heschel, The Aryan Jesus: Christian Theologians and the Bible in Nazi Germany (Princeton, NJ: Princeton University Press, 2008), 3, 13.

${ }^{58}$ Niemöller, Here Stand I! 200.
} 
ler relates how he hears all over Germany calls for the German Evangelical Church to free itself from the "dead formulas and dogmas" that prevent it from giving and sustaining life. ${ }^{59}$ Alas, Niemöller admits, Christians are not free to just toss out whatever in the biblical texts is not to their tastes. He concludes that Christians must stand before the Hebrew Bible, before the "inexorable will" of God, and respond to his grace and mercy.$^{60}$ The irony of course is that in defending Paul and the Hebrew Bible, he diminishes the scriptural foundation of Judaism (in the Hebrew Bible) as legalistic and impoverished. Thus, Confessing Church pastors such as Niemöller critiqued attempts by members of the German Christian movement to eliminate the Jewish foundations of Christianity by drawing on anti-Judaic ideas. ${ }^{61}$ The sermons that express this anti-Judaic trope affirm an existing hierarchy that differentiates the spiritually superior from the spiritually inferior. Though the prejudice is not racial in nature, it contributes to the alienation of Jews to Christians in Nazi Germany.

But perhaps the most dangerous anti-Judaic trope used by Confessing Church pastors in Nazi Germany was that God has or is currently punishing the Jews for the rejection of Jesus. ${ }^{62}$ Remarkably, pastors used this trope not simply to criticize Jews, but to condemn pro-Nazi supporters as well. For example, a sermon by Dietrich Bonhoeffer identifies Germans of his day with Israel in rebelling against God, setting up false idols, and then reaping God's punishment as a result. $\mathrm{He}$ wrote the sermon to be delivered by his close friend and colleague (and later biographer) Eberhard Bethge at the Mission Festival in Ohlau, Silesia, on October 20, 1941. This was mere months after the start of Operation Barbarossa, Germany's invasion of the Soviet Union in June 1941. But it was also shortly after he began to hear reports of massacres on the eastern front from his collaborators in the Abwehr resistance. ${ }^{63}$ By the fall of 1941, Bonhoeffer had begun his involvement with Unternehmen 7 (Operation 7), an intricate plan to smuggle seven Jews out of Germany and into Switzerland to report on Nazi treatment of the Jewish population. ${ }^{64}$

Despite his concern and concrete actions to save Jews in Nazi Germany, Bonhoeffer still expresses anti-Judaic ideas as a clergyman. The prepared message was based in part on Jeremiah 16:21, a text that refers to God's teaching the Israelites of God's power and might. Bonhoeffer mirrors Jeremiah's admonition against his own people: a time will come when God will cease asking his people to stop idolatry, and he will eventually punish his people to set them right. In this context Bonhoeffer recalls the anti-Judaic trope that Israel is a stubborn people

\footnotetext{
${ }^{59}$ Niemöller, Here Stand I! 201.

${ }^{60}$ Niemöller, Here I Stand! 204.

${ }^{61}$ Michael, Holy Hatred, 160.

${ }^{62}$ I have found seven examples in these 910 sermons, from five different pastors that reflect this view of God's curse upon the Jews and his subsequent punishment of them.

${ }^{63}$ Eric Metaxas, Bonhoeffer: Pastor, Martyr, Prophet, Spy (Nashville, TN: Thomas Nelson, 2010), Kindle Edition, location 7080.

${ }^{64}$ Bethge, Bonhoeffer, 747-752; Metaxas, Bonhoeffer, Kindle Edition, location 7098; and Elizabeth Sifton and Fritz Stern, No Ordinary Men: Dietrich Bonhoeffer and Hans Dohnanyi, Resisters against Hitler in Church and State (New York: New York Review Books, 2013), 96-98.
} 
who have consistently rebelled against God. He writes, "There is a last resort by which God leads his people (Israel), who have repeatedly misused and resisted God's grace and have toyed with it, to lead them to the recognition of God's authority: namely, the powerful angry strike of God's hand [emphasis in the original]. ${ }^{, 65}$ Christians are the new Israel, Bonhoeffer asserts, and Christians in Germany have been struck with "war, crises, imprisonment, distress of all kinds." ${ }^{\circ 6}$ The meditation is a call for Germans to consider their response to God's "dark revelation": will they return to God or harden their hearts? Once again we see anti-Judaism used to criticize the shortcomings of Christians in Nazi Germany.

Moreover, the assertion that God has punished Jews throughout history for rebellion implicitly draws on the antisemitic trope of the Jews as biologically "wayward," a condition passed down from generation to generation. Remarkably, Bonhoeffer contends that Germans are at risk for the same kind of punishment.

The reception of these anti-Judaic sentiments is tremendously difficult to gauge. I have been unable to find any commentaries or reports from government agencies, such as the Sicherheitsdienst (Security Service, henceforth SD) or Gestapo, or in letters or diaries from colleagues or parishioners. The likely reason is that anti-Judaism had long been an aspect of Christianity and thus no one took note when it was expressed. The post-war reflection of Eberhard Bethge- the same friend, colleague, and biographer of Bonhoeffer-illuminates the mind-set of German citizens (and not just pastors) under the Nazi regime. In 1989, Bethge gave a talk criticizing the antisemitism of various resistance figures, and he sent a letter to one German critic of his talk. Bethge argued that "the 'old tradition' of Christian anti-Judaism had converged with the radical anti-semitism of Nazism. ${ }^{, 67}$ Bethge writes,

[W] have simply been long, long blind and-without having been radical anti-Semites - nonetheless we were in our language and consciousness the bearers of unholy potential. I see the problem in that even extraordinary resistance fighters were at the same time still sunk in the kind of language and attitudes whose anti-Jewish content could only be made clear decades after $1945 .^{68}$

Bethge speaks of "we" not only to disarm his critics, but to argue the pervasiveness of anti-Judaism even among those who were not "radical anti-Semites." 69

The anti-Judaic comments in these sermons indicate that some Confessing Church pastors interpreted the situation of the Jews in Nazi Germany through a

\footnotetext{
${ }^{65}$ Dietrich Bonhoeffer, Conspiracy and Imprisonment, 1940-1945 (Minneapolis: Fortress Press, 2006), 625 .

${ }^{66}$ Bonhoeffer, Conspiracy and Imprisonment, 625.

${ }^{67}$ John W. De Gruchy, Daring, Trusting Spirit: Bonhoeffer's Friend Eberhard Bethge (Minneapolis: Fortress Press, 2005), 190

${ }^{68}$ Quoted in De Gruchy, Daring, Trusting Spirit, 191.

${ }^{69}$ De Gruchy, Daring, Trusting Spirit, 191.
} 
theological lens, and yet this opened the door to implicit antisemitic connections. This research supports the assertion that the primary concern of pastors in relation to the Jewish people was "right belief" and conversion, not their material condition as a people group targeted by the Nazi regime for exclusion from German public life. ${ }^{70}$

\section{Voices of Support for Jews and Judaism from the Pulpit}

Though pastors periodically expressed anti-Jewish sentiments from the pulpit, they also expressed views supportive of Jews and Judaism, thus opposing National Socialist ideology and racial policies, and at the same time distinguishing themselves from the explicit antisemitic perspectives of the pro-Nazi German Christian movement. Of the 910 sermons I have examined, forty articulate perspectives that defend Jews or Judaism. The sermons can be grouped according to the following themes: first, Judaism is a foundation for the Christian faith; second, the Jews are the people of God and must be respected as such; third, there is no qualitative difference between Jews and other people groups, and thus they should be treated equally; and fourth, condemnations of the persecution of Jews. Regardless of the pastors' motivations or intentions, the pastors' religiously-based pronouncements in support of Jews and Judaism took on political significance as implicit or explicit criticisms of Nazi ideology and racial policy. ${ }^{71}$ Thus, surprisingly, both negative and positive expressions about Jews could serve to criticize the Nazi regime, the German Christian movement, or Germans more generally in Nazi Germany. This reveals the tremendous complexity and ambivalence that characterized the thinking about Jews in Nazi Germany.

The first major theme in these forty sermons that support or defend the Jews and Judaism is the expression that the Jews are the chosen people of God, the people whom God has chosen to enter into covenant with and to preserve his revelation. This is the most common theme in these forty sermons, occurring eighteen times. The expressions would often be concise, straightforward statements that the Jews are the special people of God. For example, Karl von Schwartz, the cathedral pastor of Braunschweig and also the provost of the St. Marienberg monastery, often refers to the Jews as a "chosen" or "special" people of God. I counted five different sermons in which he deliberately pointed out the chosen-ness of the Jewish people, which is more than any other single pastor. ${ }^{72}$ Interestingly, these sermons were part of a collection published by Hellmuth Wollermann's Verlagsbuchhandlung in Braunschweig in late 1933 (though some may have been preached earlier). The unusual characteristic of this collection is that the sermons were based on Hebrew Bible texts. Clearly, Schwartz believed that

\footnotetext{
${ }^{70}$ See Friedländer, Nazi Germany and the Jews, Vol. 1, 43-44; and Gerlach, And the Witnesses Were Silent, 7.

${ }^{71}$ See Victoria Barnett, For the Soul of the People (New York: Oxford University Press, 1992), 92.

${ }^{72}$ See Karl von Schwarz, Gottes Wort an Gottes Volk, Ein Jahrgang Predigten (Braunschweig: Hellmuth WollermannVerlagsbuchhandlung, 1933).
} 
Christians needed to become more acquainted with the Hebrew Bible and the Jews as the people of God.

This positive view of the Jews - that they are blessed and special-aroused the concern of the Nazi regime because it blatantly undermined Nazi racial ideology. Gestapo and SD reports give us insight into the Nazi regime's reception of these public pronouncements by Confessing Church pastors that the Jews are the chosen people of God. A Gestapo report from Berlin on December 1, 1939, relates that a Confessing Church pastor by the name of Eberle in Hundsbach (in the district of Kreuznach) was arrested because he said in a sermon, "The God of our Church is the Jewish God of Jacob, to whom I confess... In 1932, I stood in Saarbrücken together with 3000 faithful Protestants. Since that time, more and more are falling away from the Protestant faith." ${ }^{, 73}$ This report is unique because it reports a rare instance, as far as I have been able to uncover, of the Nazi regime actually arresting a pastor solely due to the content of a sermon. But what is more, the "offensive" remarks were not about Hitler or the Nazi leadership per se; instead, the pastor was arrested for publicly acknowledging that the Christian God is the Jewish God and that Christianity is in decline in the Third Reich. The offense was in identifying the Jewish God as the Christian God, and that indeed Christianity owes much to Judaism. The assertion that Christians and Jews have the same God closely binds the two together as God's people, and this contradicts Nazi racial ideology that denigrates Jews as inferior human beings.

A second theme in these sermons that support Jews and Judaism is belief that Judaism is the foundation of Christianity and, as such, Christians should value and appreciate the Hebrew Bible. This assertion directly undermines efforts of the German Christian movement to denigrate the Hebrew Bible and remove it from the Christian canon, as epitomized in the Institute for the Study and Eradication of Jewish Influence on German Religious Life. ${ }^{74}$ I have found nine occurrences of this theme in these forty sermons. The Lutheran pastor and theologian Hans Iwand of the Marienkirche in Dortmund, delivered a sermon focusing on the theme of Christianity's foundation in Judaism on August 2, 1941, just a couple months after the Nazis began the invasion of Russia earlier that summer. Up to this time, Hitler and the Nazi regime had not developed a clear and consistent policy concerning European Jewry, yet the war against Russia proved a turning point. ${ }^{75}$ As the Wehrmacht conquered new territory, the Einsatzgruppen of the SS followed and massacred Jews and Soviet "commissars" and on an unprecedented scale. ${ }^{76}$ By August 1941, hundreds of thousands of Jews had been massacred by

\footnotetext{
${ }^{73}$ Heinz, Boberach, ed., Berichte des SD und der Gestapoüber Kirchen und Kirchenvolk in Deutschland 1934-1944 (Mainz: Matthias-Grünwald-Verlag, 1971), 376.

${ }^{74} \mathrm{Heschel}$, Aryan Jesus, 3 and 13.

${ }^{75}$ See Karl Schleunes, The Twisted Road to Auschwitz: Nazi Policy toward German Jews 1933-1939 (Chicago: University of Illinois Press, 1990); Christopher Browning, with contributions by Jürgen Matthäus, The Origins of the Final Solution: The Evolution of Nazi Jewish Policy, September 1939March 1942 (Lincoln, NE: University of Nebraska, 2004); and Ian Kershaw, Hitler, the Germans, and the Final Solution (New Haven: Yale University Press, 2008).

${ }^{76}$ See Browning, Origins of the Final Solution, 252-63; Lucy Dawidowicz, The War Against the Jews, 1933-1945 (New York: Holt, Rinehart and Winston, 1975), 125-140; Saul Friedländer, Nazi
} 
Nazi forces and their allies in Lithuania, the Ukraine, Bialystok, Romania, Belorussia, and the Soviet Union, among other war zones. ${ }^{77}$ It is possible that Iwand had not heard news of the Jewish massacres in the war zones, but he had to be aware of anti-Jewish policies closer to home: the expulsion of Jews from public and professional life was long underway, the "Aryanization" of Jewish property and businesses increased since 1937 and 1938, and the ghettoization of Polish Jews began shortly after the start of World War II. ${ }^{78}$ And after the Nazi invasion of Poland in September 1939, Jews throughout Europe would be systematically labeled with a yellow Star of David and thus targeted for persecution. Iwand himself was particularly sensitive to the problem of Nazi persecution of Christians of Jewish descent. The Nazi regime classified his wife Ilse as Mischling ("mixedbreed") first class, meaning that she had two grandparents of the Jewish faith. ${ }^{79}$

Iwand's sermon affirms that the source of the gospel comes from Israel, and argues that a denial of this fact is at best ignorance. Commenting on Galatians 1:10-24, a text in which the Apostle Paul discusses the source of his revelation, Iwand argues,

Do you think you could perhaps go back on the wide strand of the gospel and you could then visit from where the source comes, and you could discover that the source comes from a land, and you could discover that the source comes from a land that is Jewish, and then you come to God and say, Is the source something dirty, as if there is a spirit that we must bring out? ${ }^{80}$

Iwand challenges the perspective of Christians like those in the pro-Nazi German Christian movement who devalue the Hebrew Bible and Judaism because they fail to appreciate the relationship between Christianity and Judaism. ${ }^{81}$ They cannot acknowledge the debt that Christianity owes to Judaism. For Confessing Church pastors like Iwand, this is a failure to understand from where revelation ultimately comes, and that is, as Paul affirms, "from above."

Confessing Church pastors preached against excising the Hebrew Bible from Christianity - without it, Christianity loses its source and foundation. Thus, these

Germany and the Jews: The Years of Extermination, 1939-1945 (New York: Harper Perennial, 2008), 207-225; and Timothy Snyder, Bloodlands: Europe Between Hitler and Stalin (New York: Basic Books, 2010), 126-127, 182-200.

${ }^{77}$ Deborah Dwork and Robert Jan van Pelt, Holocaust: A History (New York: W.W. Norton, 2002), 266-278.

${ }^{78}$ The earliest rumors of mass killings of Jews are found as early as autumn 1941, though by mid1942 rumors circulated far and wide and reports were even broadcast by the BBC by autumn 1942. See Ian Kershaw, Hitler, The Germans, and the Final Solution (New Haven, CT: Yale University Press, 2008), 142; and also Walter Laqueur, The Terrible Secret: Suppression of the Truth about Hitler's "Final Solution" (New York: Little Brown \& Co., 1981).

${ }^{79}$ Dr. F.W. Arnold. Report of the Kirchliche Hilfsstelle für evangelische Nichtarier (Büro Pfarrer Grüber. 21 December 1938. Nichtarische Geistliche Kirchengemeindebeamte, Gemeindevertreter usw., von Oktober 1933 bis Dezember 1952. EZA 7/1952.

${ }^{80}$ Hans Joachim Iwand, Nachgelassene Werke, Dritter Band (München: Chr. Kaiser Verlag, 1963), 92.

${ }^{81}$ See Bergen, Twisted Cross, 26-27. 
sermons represent a stake in the ground for the Confessing Church that the Hebrew Bible must not be alienated from the Christian tradition. ${ }^{82}$ In this sense, the Confessing Church pastors stand in stark contrast to members of the German Christian movement and Nazi supporters who condemned the Hebrew Bible as immoral, as a thoroughly "Jewish book," as "un-German," and inconsonant with "Aryan" morality. ${ }^{83}$

We know from Gestapo and SD reports that the Nazi regime was concerned when pastors defended Judaism from the pulpit. Unfortunately, the reports do not mention whether or not the pastors were Confessing Church members. Nevertheless, the reports are instructive. For example, one describes how a pastor Ulricht of Prenzlau gave a sermon on January 1, 1934, and lamented the paganization of Christianity in the one year since the establishment of the Nazi dictatorship. ${ }^{84} \mathrm{Ul}-$ richt drew a connection between the Christ whom the Nazis "forgot" and how the Jews were denied full participation in German life.

Man idolizes today great men who have achieved much, but the Christ who let himself be nailed to the cross, whom one forgets, he is no longer considered. Jesus Christ was also a Jew, yes indeed, but the faith teaches: Go into the world and make disciples of all the peoples, etc. If a Jew cannot be a German, so can he very well — and I stress this explicitly—be a good Christian. $^{85}$

This statement not only condemns Nazi ideology and those who "forget" Christ, but at the same time it connects into one community all individuals who desire to be Christian, regardless of nationality or culture. Ulricht's statement caught the attention of the Gestapo because he claims Jews can be good Christians, even if the Nazis declare they cannot even be good Germans. He affirms that German identity, in truth, is less important than Christian identity. Statements such as these clearly caught the attention of the Gestapo as public expression of opposition to National Socialism.

Why would the Nazi regime have been concerned with such statements? These are religious statements of faith that do not explicitly advocate active resistance to the Nazi regime, whether in the form of protests or violent confrontation or even unity with Jews in a common cause. But the implications were troubling to the Nazi regime. The Gestapo and SD took notice of these sermons as evidence that the German churches were sites in Nazi Germany where pastors could publically express anti-Nazi ideas and pro-Jewish sentiment. ${ }^{86}$

\footnotetext{
${ }^{82}$ Arthur Cochrane, The Church's Confession under Hitler (Philadelphia: Westminster Press, 1967), 184-185; see also Barnett, For the Soul of the People, 234; and Carroll, Constantine's Sword, 38, 568.

${ }^{83}$ Bergen, Twisted Cross, 144.

${ }^{84}$ Gestapo Report on Pastor Ulricht: "Staatsfeindliches Verhalten evangelischer Geistlicher, v.a. der Bekennenden Kirche, 1934-1935," Papers of the Reichssicherheitshauptamt, BA R58/5679.

${ }^{85}$ Gestapo Report on Ulricht, "Staatsfeindliches Verhalten evangelischer Geistlicher," BA R58/5679.

${ }^{86}$ See Hoffmann, The History of German Resistance, 13; and Kershaw, Hitler, the Germans, and the Final Solution, 166.
} 
The third and last theme expressed in these Confessing Church sermons is the condemnation of Nazi persecution of the Jews. This theme only occurs nine times in these 910 sermons. I have found just a couple cases of pastors speaking about the persecution of Jews before World War II. For example, Dietrich Bonhoeffer delivered the funeral oration after the death of his grandmother, Julie Bonhoeffer, in Berlin on January 15, 1936, just months after the passage of the Nuremberg Laws in September 1935. While recalling fond memories of his grandmother, Bonhoeffer tells of how troubled she was that the principles of her youth - "the inflexibility of law, the free word of free men, the binding quality of the given word, plain and sober speech, honesty and simplicity in personal and public life" - had been betrayed during the Nazi dictatorship. ${ }^{87}$ She could not keep quiet amid this betrayal, he says. "Therefore her last years were deeply troubled by the great sorrow she bore for the suffering and fate of the Jews among our people. She sought to help and suffered with them. She stemmed from a different age, out of a different spiritual world. This world does not sink with her into the grave." ${ }^{88}$ Bonhoeffer emphasizes the strange-ness of Nazi values to the world in which his grandmother Julie lived. While Bonhoeffer's sermon celebrates this courageous and principled woman, it is even more significant that he makes her a model for his family to emulate in troubled times. He says that the inheritance that Julie gave his family - this strength of character and great courage - was in the form of an "obligation" to emulate her example as fellow "strangers" in Nazi Germany.

One of the most remarkable sermons about the Nazi persecution of the Jews was in response to the nation-wide pogrom on the night of November 9-10, 1938. For Pastor Julius von Jan of Oberlenningen, the pogrom known as Kristallnacht, the night of broken glass, marked a decisive moment in his career. ${ }^{89} \mathrm{He}$ preached a sermon a week later on 16 November 1938, in which he sought to expose the criminal behavior of his fellow Germans whose passions and hatred had run amok. ${ }^{90}$ The Nazi regime fomented the pogrom in response to an event on November 7, 1938, when a seventeen-year-old Pole named Herschel Grynszpan shot and fatally wounded a junior official, Ernst vom Rath, of the German embassy in Paris. Grynszpan's grievance concerned another Nazi policy of persecution against the Jews, this time the deportation of foreign-born Jews living in Germany. The Polish government closed its borders to 8,000 of the 12,000 Polish refugees, and Grynszpan's parents were among those stranded at the border. ${ }^{91}$ Rath died of his injuries in the afternoon on 9 November 1938, which gave the

\footnotetext{
${ }^{87}$ Dietrich Bonhoeffer's Christmas Sermons, edited and translated by Edwin Robertson (Grand Rapids: Zondervan, 2005), 123.

${ }^{88}$ Bonhoeffer's Christmas Sermons, ed. Robinson, 123.

${ }^{89}$ See Dean G Stroud, Preaching under Hitler's Shadow: Sermons of Resistance in the Third Reich (Grand Rapids, MI: Eerdmans, 2013). The work is an edited collection of sermons and profiles of the pastors who delivered them. For more on Jan, see Conway, Nazi Persecution of the Churches, 375376; and Barnett, For the Soul of the People, 142.

${ }^{90}$ Conway, Nazi Persecution of the Churches, 375; and Stroud, Preaching under Hitler's Shadow, 123.

${ }^{91}$ Martin Gilbert, Kristallnacht: Prelude to Destruction (New York: HarperCollins, 2006), 23.
} 
Nazi regime an opportunity for reprisal against the Jews of Germany. Within twenty-four hours, and at Hitler's instigation, Nazi thugs destroyed 1000 synagogues and over 7500 Jewish-owned businesses, filling the streets of Germany with broken glass. ${ }^{92}$ The best figure for the number of Jews arrested is approximately 30,000, an astounding number, marking the first time that Jews as Jews were arrested en masse and sent to concentration camps. ${ }^{93}$ While Nazi records indicate that 91 men died in the pogrom, another 300 Jews, at the depths of despair, committed suicide it its wake. ${ }^{94}$

Most clergymen were silent about the pogrom the following week, revealing timidity and a concern only for their own. ${ }^{95}$ Nevertheless, a few Confessing Church pastors did speak out the next week in church services, Jan among them. His sermon was based on Jeremiah 22:2-9, which declares the prophet's role in proclaiming the law of God to his nation, king, and princes who have trampled upon it. ${ }^{96}$ In the first few lines, Jan accuses the Nazi regime for jailing God's prophets, and also condemns the German-Christians as posers and liars. A crime has been committed in Paris, he argues,

Passions have been released, the laws of God jeered at, houses of God that were sacred to others have been burned to the ground, property belonging to the foreigner plundered or destroyed, men who faithfully served our nation (Volk) and who fulfilled their duty in good conscience have been thrown into concentration camps simply because they belong to another race... Even if the authorities do not admit their hand in this injustice, the healthy sensitivity of the people (Volk) feels the truth without any doubt-including where people do not dare speak of this. ${ }^{97}$

The German people have lost their way and followed not simply a political religion, but an "organized anti-Christianity," established by the state and administered by German-Christians. ${ }^{98}$ Germans have burned "houses of God" to the ground - note he does not say Synagoge but Gotteshäuser to bridge the distance some might see in the houses of worship of the two traditions. He echoes the prophet Jeremiah: "God will not be ridiculed. What a person sows, he will reap!" 99 The people know that God's judgment is coming unless they repent of what they have done.

\footnotetext{
${ }^{92}$ See Barnett, For the Soul of the People, 139; Gilbert, Kristallnacht, 28-29, and 118; and Richard Evans, The Third Reich in Power (New York: Penguin, 2005), 581.

${ }^{93}$ Evans, Third Reich in Power, 581.

${ }^{94}$ In fact, the true figure of those murdered may run between one and two thousand. See Evans, Third Reich in Power, 590.

${ }^{95}$ Barnett, For the Soul of the People, 142; and Evans, Third Reich in Power, 581.

${ }^{96}$ Julius von Jan, "O Land, Land, Land: Hear the Word of the Lord!" in Stroud, Preaching under Hitler's Shadow, 121.

97 Jan, "O Land, Land, Land," in Stroud, Preaching under Hitler's Shadow, 123.

98 Jan, "O Land, Land, Land," in Stroud, Preaching under Hitler's Shadow, 123.

99 Jan, "O Land, Land, Land," in Stroud, Preaching under Hitler's Shadow, 124.
} 
Word of Jan's sermon spread. Nearly two weeks later, on 25 November at 10:30 pm, a mob of 500 demonstrators found Jan, beat him senseless, and took him to the Town Hall for an hour-long interrogation, which resulted in incarceration in the country prison for four months. ${ }^{100}$ One year later, on 15 November 1939, Jan was tried before the Nazi "special court" (Sondergericht) and condemned for "misusing the pulpit" and "treachery." "101 His sentence was 16 months. Jan was able to continue preaching after his release in May 1940, but was drafted into the Wehrmacht in 1943 and served on the Russian front, ultimately surviving the war. Jan's story illustrates the danger and costs the Confessing Church pastor faced if he decided to speak out boldly against Nazi persecution and in support of the Jews.

German pastors were certainly aware of the Nazi persecution of the Jews, though the extent of this knowledge is not certain, particularly regarding the details of the Holocaust. Strikingly, these nine cases of Confessing Church pastors speaking out against the persecution of the Jews represent a minuscule fraction of the 910 sermons I have examined. Even in these instances, the pastors most often do not give specifics about the persecution, or the identities of the persecutors, or even the nature of the crimes being committed against the Jews.

My research presents a significant problem given the historiography of the German population's knowledge of the Nazi mass murder of European Jewry, which has been extensively examined. ${ }^{102}$ Conservative estimates are that by 1942 and 1943, approximately one-third of the German population had received news in one form or another of the mass murder of the Jews. ${ }^{103}$ If we exclude teenagers and children from this equation - those whose parents might have "shielded" them from such knowledge-less conservative estimates indicate that perhaps one-half of the population was aware of the atrocities. ${ }^{104}$ This would of course include Confessing Church pastors. And yet my findings indicate that less than one percent of the 910 sermons make mention of the atrocities and persecutions. Knowledge of Nazi atrocities spread to Germans of all socioeconomic and educa-

\footnotetext{
${ }^{100}$ Gerlach, And the Witnesses Were Silent, 144.

${ }^{101}$ The following biographical background is based on Stroud, Preaching under Hitler's Shadow, 119. See also Conway, Nazi Persecution of the Churches, 375-376; and Barnett, For the Soul of the People, 142.

102 Marlis Steinert, Hitler's War and the Germans: Public Mood and Attitude during the Second World War, translated by Thomas de Witt (Athens: Ohio University Press, 1977); Walter Laqueur, The Terrible Secret: An Investigation into the Suppression of Information about Hitler's "Final Solution" (London, 1980); Ian Kershaw, Popular Opinion and Political Dissent in the Third Reich: Bavaria 1933-1945 (New York: Oxford University Press, 1983); Hans Mommsen, "What did the Germans Know about the Genocide of the Jews?" in Walter H. Pehle, ed., November 1938: From 'Kristallnacht' to Genocide (New York: Berg, 1991), 187-221; David Bankier, The Germans and the Final Solution: Public Opinion Under Nazism (London, 1992); Hans Mommsen and Volker Ullrich, "'Wir haben nichts gewusst': Ein deutsches Trauma," 19994 (1991): 11-46; Eric A. Johnson and KarlHeinz Reuband, What We Knew: Terror, Mass Murder, and Everyday Life in Nazi Germany, An Oral History (Cambridge, MA: Basic Books, 2005); and Frank Bajohr and Dieter Pohl, Der Holocaust als offenes Geheimnis: Die Deutschen, die NS-Führung und die Allierten (München: C.H. Beck, 2006).

${ }^{103}$ Johnson and Reuband, What We Knew, 39. Also, Laqueur argues that "news of the 'final solution' had been received in 1942 all over Europe" (emphasis added), see The Terrible Secret, 196.

${ }^{104}$ Johnson and Reuband, What We Knew, 392.
} 
tional backgrounds through widely-listened to $\mathrm{BBC}$ broadcasts and also reports of Wehrmacht soldiers returning home from the eastern front. ${ }^{105}$

At the same time, we must also consider the impact of the Nazi propaganda machine on Germans throughout World War II. Through the constant barrage of propagandistic speeches by Hitler, Joseph Goebbels, and other Nazi leaders, broadcast across Germany, as well as wall posters strategically positioned throughout commuter and pedestrian traffic, the Nazi regime used unambiguous language to express their approach to the "Jewish menace"; they used words such as Vernichtung (extermination) and Ausrottung (annihilation). ${ }^{106}$ The regime reached millions upon millions of Germans who could not help but be exposed to the pervasive propaganda and thereby become informed of the Nazi approach to the Jewish people. It has even been argued that by mid-1942, knowledge of "the mass crimes of the Nazis, and in particular the murder of the Jews, was an open secret in the Reich and among the Allies." 107 There was simply no possibility of keeping crimes so immense a secret hidden from Germans and the peoples of occupied Europe, not with the murders taking place throughout much of Eastern Europe, the millions of victims involved, and the incredible inhumanity of the crimes. ${ }^{108}$ Many Confessing Church pastors, who were leaders in their religious communities and ministers to families with sons at war, "who kept their eyes and ears open," would have known about the Nazi mass murder of the Jews. ${ }^{109}$

How might we account for the extraordinarily low percentage of sermons that address the Nazi persecution of the Jews? A few factors might shed some light on this problem. First, we should keep in mind that for most Germans the war and its progress were of utmost concern, not the fate of the Jews. ${ }^{110}$ As Ian Kershaw writes, "The Jews were out of sight and literally out of mind for most." " Second, we must consider the nature of the knowledge of Nazi atrocities among the German population. While millions of Germans knew of the Nazi massacres of Jews, most failed to put all the puzzles pieces together to see the full picture the Holocaust; they simply could not fathom the systematic extermination of all European Jewry. ${ }^{112}$

A third reason for the lack of response in sermons was a sense of hopelessness and powerlessness that many must have felt living in a totalitarian society. ${ }^{113}$

\footnotetext{
${ }^{105} \mathrm{BBC}$ broadcasts provided constant news updates of atrocities and mass murders. See Bankier, The Germans and the Final Solution, 113; Johnson and Reuband, What We Knew, 396-397; Mommsen, What did the Germans Know?" 206; and Laqueur, The Terrible Secret, 201.

${ }^{106}$ Jeffrey Herf, The Jewish Enemy: Nazi Propaganda during World War II and the Holocaust (Cambridge, MA: Bellknap Press, 2006), 267.

${ }^{107}$ Bajohr and Pohl, Der Holocaust als offenes Geheimnis, 128.

${ }^{108}$ Bajohr and Pohl, Der Holocaust als offenes Geheimnis, 128.

${ }^{109}$ Johnson and Reuband, What We Knew, 397.

${ }^{110}$ Mommsen, "What did the Germans Know?" 192; and Kershaw, Popular Opinion, 360.

${ }^{111}$ Kershaw, Popular Opinion and Political Dissent in the Third Reich, 364.

${ }^{112}$ Mommsen, "What did the Germans Know?" 206, 209; and Bankier, The Germans and the Final Solution, 115.

${ }^{113}$ Mommsen, "What did the Germans Know?" 205; Bankier, The Germans and the Final Solution, 103; and Laqueur, The Terrible Secret, 208
} 
The news of atrocities would have presented a challenge to pastors: one could ask questions, investigate the stories, speak out against the Nazi regime, and reap the consequences, including possible arrest and imprisonment, or worse. Or one could remain silent, refuse to follow up on news of atrocities, and continue serving the congregation, hoping to outlive the Nazi regime. In the end, as the historian David Bankier writes, many Germans-and many pastors-"knew enough to know that it was better not to know more." 114 The Confessing Church pastors behaved just like the vast majority of Germans in not speaking out in support of Jews facing Nazi persecution, and this reflects several factors: a sense of resignation that there is nothing to be done but wait for the regime to topple; a significant degree of repression under the watchful eyes of the regime's police apparatus, the Gestapo agents and their networks of informers; and also the moral desensitization of nearly a decade witnessing the day-by-day, step-by-step, exclusion of the Jewish people from German public life. ${ }^{115}$

But we must also take into account the anti-Jewish prejudice expressed in the Confessing Church pulpits. The evidence supports the historiography of the churches in Nazi Germany that anti-Jewish prejudice was pervasive among Christians. ${ }^{116}$ Sermons that repeat centuries-old tropes that portray Jews as wayward, stubborn, as guilty of murdering Christ, and as divinely punished throughout history, could serve to mitigate any compassion or empathy that a Christian might otherwise feel for their persecuted Jewish neighbors. I would assert that this "unholy potential," as Bethge describes it, prevented pastors from speaking out more forcefully and often in support of Jews and Judaism.

While these relatively few instances of Confessing Church pastors expressing concern about the persecution of Jews are important in and of themselves, the fact that there are so few from the rank and file of the "oppositional" faction of the German churches underscores the muted voice of Germany's pastors during the ghettoization, deportation, and extermination of European Jewry. Peter Fritzsche argues that in German society there was a "general silence" about the suffering and fate of the German Jews in Nazi Germany, a silence that filled the sanctuaries of German churches as well. ${ }^{117} \mathrm{He}$ makes an interesting point that the fate of the Jews lay beyond the Germans' "limits on empathy" because they simply could not imagine being Jewish. While Germans (and Christians) debated the Nazi policy of euthanasia because they could actually imagine this policy causing the suffering of their own families, at the same time "they could not imagine being Jewish" and suffering simply for this reason. ${ }^{118}$ But as all the sermons indicate, Christians had a wealth of religious concepts and principles that could (one might

\footnotetext{
${ }^{114}$ Bankier, The Germans and the Final Solution, 115.

${ }^{115}$ Mommsen, "What did the Germans Know?" 205; Bankier, The Germans and the Final Solution, 103; and Laqueur, The Terrible Secret, 208.

${ }^{116}$ See Michael, Holy Hatred; Probst, Demonizing the Jews; and also Friedländer, Nazi Germany and the Jews, Vol. 2, 56.

${ }^{117}$ Peter Fritzsche, Life and Death in the Third Reich (Cambridge: Harvard University Press, 2009), 119.

${ }^{118}$ Fritzsche, Life and Death in the Third Reich, 119.
} 
say should) have aided this imagination. Christians share much of the same sacred history, the same sacred stories that inform and shape moral behavior and spiritual growth. One could argue that this common heritage should have been utilized more often and more explicitly to bond Christians and Jews together in Nazi Germany.

Yet it is remarkable that after the war many Germans had no problem imaging themselves as the persecuted minority. The emphasis on German suffering was quite common among post-war German leaders, especially church leaders, who argued for the victimization of Germans under the Nazi dictatorship and also the Allied conquest of Germany, thus casting themselves as survivors. ${ }^{119}$ Some went so far as to liken the Nazi treatment of the Confessing Church to the Hebrew Bible's depiction of Israel's suffering under Egyptian and Babylonian persecutions. For example, shortly after the war's end in July 1945, the bishop of BerlinBrandenburg, Otto Dibelius, delivered a sermon in which he explicitly claimed that "the Lord with his mighty hand has delivered us [the Confessing Church] from the power of the Devil and led us out of Egypt, out of the house of servitude." 120 As Susannah Heschel has argued, both Confessing Church members and German-Christians appropriated the identity of the Jews in the Hebrew Bible to describe the recent calamity of Germans "who had been liberated from Hitler but conquered by the Allies; having murdered the Jews, the Germans could now take their identity." 121 Confessing Church leaders identified themselves with biblical Israel, and in the process exonerated themselves as honorable instruments of God that confronted an oppressive kingdom. Yet ironically, as the "new Israel" they overwhelmingly failed to speak out for persecuted Jews under the Nazi regime.

\section{Conclusions}

We can draw several conclusions based on the evidence I have presented. The expressions of prejudice revealed in these sermons may overwhelmingly be categorized as non-rational or anti-Judaic, meaning the prejudice is based on religious convictions founded in scripture and a Christian reading of history. In other words, the prejudice expressed is based primarily on explicit religious convictions, not racial convictions. When implicit antisemitic tropes are articulated, they always serve religiously-based anti-Judaic assertions. The anti-Jewish prejudice

\footnotetext{
${ }^{119}$ See also the Stuttgart Declaration of Guilt, October 1945. This document was drawn up by the Council of the Evangelical Church in Germany and refers to the German people as a "Gemeinschaft der Leiden," a "community of suffering." See Heschel, The Aryan Jesus, 279-281; Matthew Hockenos, A Church Divided: German Protestants Confront the Nazi Past (Bloomington, IN: Indiana University Press, 2004), 46-47, 52-54, and 187; Spotts, Churches and Politics, 62-69; and Bill Niven, ed., Germans as Victims: Remembering the Past in Contemporary Germany (New York: Palgrave, 2006), 1-21; Robert G. Moeller, War Stories: The Search for a Usable Past in the Federal Republic of Germany (Berkeley, CA: University of California Press, 2001), 3-4, 44-48; and Steven M. Schroeder, To Forget It All and Begin Anew: Reconciliation in Occupied Germany, 1944-1954 (Lincoln, NE: University of Toronto Press, 2013), 9, 40-44.

${ }^{120}$ Quoted in Hockenos, A Church Divided, 52.

${ }^{121}$ Heschel, The Aryan Jesus, 279.
} 
in these sermons contrasts to the explicit antisemitism of the German Christian movement, which utilized the irrational antisemitic prejudiced, based on fear, paranoia, and envy. ${ }^{122}$ Moreover, I have not found one instance of Confessing Church pastors using Nazi racial terminology - such as Untermenschen (subhumans) - to denigrate the Jewish people, or blame the Jews for Germany's problems since World War I, again in contrast to the German-Christians. Thus, the prejudice against the Jews expressed in these Confessing Church sermons relies upon traditional Christian tropes found throughout the history of the Church.

Yet the sermons reveal just how anti-Judaic prejudice may interact with antisemitic tropes. We must keep in mind that the expressions of anti-Judaism revealed in these sermons have the potential to overlap with Nazi racial antisemitism in German society, and thereby possibly advance the exclusion of Jews from public life. For example, if a pastor argues that God has punished the Jews as an accursed people since the crucifixion of Christ, then the implications in Nazi Germany are potentially devastating. The congregant may generalize and perceive that the Jews as a people group are evil, pernicious, and immoral; that they conspire to dominate, to destroy Christianity, and thus, that they cannot be trusted. ${ }^{123}$ While anti-Judaic tropes may originate in churches, we should expect these ideas to interact and overlap with other secular ideas outside church doors. Scholars have recently contributed much to understanding how religious anti-Judaism blended with antisemitism in academia. ${ }^{124}$

My analysis also reveals that Confessing Church pastors often used antiJudaic expressions for a purpose, not only to advocate for the superiority of Christianity to Judaism, but to criticize the Nazi regime and even the German people. They compared the Jews to Nazis as hard-hearted, obsessed with race consciousness and the racial purity of the people, as legalistic, weak, and erroneously convinced of their own "superiority" and "chosen-ness." Again, these comments draw on the antisemitic trope that accuses the Jews of tribalism - taking pride in a false ethno-nationalist identity that denies equality with other groups. Thus, ironically, Confessing Church pastors combated overt Nazi racial ideology by using antisemitic tropes. This demonstrates that anti-Jewish expressions were not often simply extemporaneous comments, or merely meant to denigrate Jews in Germany society, but they were often employed purposefully to challenge the Nazi regime and its racial policies and ideology.

The sermons also reveal evidence of a historic dilemma Christians have in relating to Jews and Judaism. On the one hand, Judaism plays a central role in the Christian tradition; from Jesus' ministry in a Jewish context to the inclusion of the Hebrew Bible in the Christian canon, Christianity affirms Jewish religious ex-

\footnotetext{
${ }^{122}$ See for example, Bergen, Twisted Cross; Robert Ericksen, Theologians under Hitler: Gerhard Kittel, Paul Althaus, and Emanuel Hirsch (New Haven, CT: Yale University Press, 1985); and Heschel, The Aryan Jesus.

${ }^{123}$ Michael, Holy Hatred, 12.

${ }^{124}$ See for example, Robert Ericksen's Theologians under Hitler, and Complicity in the Holocaust: Gerhard Kittel, Paul Althaus, Emanuel Hirsch (New Haven: Yale University Press, 1985), and also Heschel's The Aryan Jesus.
} 
perience and God's covenant with Israel. On the other hand, elements of the Christian tradition stemming all the way back to its biblical texts present Jews as "Christ-killers" and as an accursed people. ${ }^{125}$ The ambivalence is palpable. Furthermore, the low percentage of sermons that expressed support of Jews and Judaism reveals a missed opportunity for pastors to draw connections between Christians and Jews in a shared religious tradition.

The importance of these sermons is reflected in the concern that the Gestapo and SD paid to pastors who spoke out in support of Jews from the pulpit. Government reports indicate that the Nazi regime was indeed concerned about Confessing Church pastors not simply supporting and defending Jews, but developing connections between Christians and Jews based on their shared traditions and values. The evidence suggests that Confessing churches had the potential to become sites of support and sympathy for Jews in Nazi Germany, a place where Christians could develop their imagination-based on common theological concepts and stories - to place themselves in the situation of persecuted Jews. The mere fact that only 40 of 910 sermons made pro-Jewish statements indicates that this was a missed opportunity to shape the imagination and behavior of Christians.

To the attentive congregant sitting in a pew in Nazi Germany, the sermons of the Confessing Church present an ambivalent perspective of the Jews and Judaism. She might have heard an occasional positive word about the Jews, or about the inextricable connections between Judaism and Christianity. But at the same time, she might have heard a harsh word that reflects centuries of anti-Judaic prejudice that condemns Jews as wayward and deserving of God's punishment. These sermons reveal that anti-Judaic theology in twentieth-century German Protestantism became an impediment to Confessing Church pastors proclaiming clear and unequivocal messages about Jews as the spiritual cousins of Christians and Judaism as a valued and inextricable foundation for Christianity - messages sorely needed in Nazi Germany.

\footnotetext{
${ }^{125}$ Michael, Holy Hatred, 16-19.
} 